\title{
Short Selling around Dividend Announcements and Ex-Dividend Days
}

\author{
Benjamin M. Blau \\ Department of Economics and Finance \\ Utah State University \\ 435-797-2340 \\ ben.blau@usu.edu \\ Kathleen P. Fuller \\ Department of Finance \\ University of Mississippi \\ 662-915-5463 \\ kfuller@bus.olemiss.edu \\ Robert A. Van Ness \\ Department of Finance \\ University of Finance \\ 662-915-6940 \\ rvanness@bus.olemiss.edu
}

Current Version June 23 ${ }^{\text {rd }}, 2009$

We would like to thank session participants at the 2007 Financial Management Annual Meeting in Orlando, Florida and the 2007 Southern Finance Annual Meetings in Charleston, South Carolina for comments and suggestions. We also thank Ramon DeGennaro for insightful comments. 


\title{
Short Selling around Dividend Announcement and Ex-Dividend Days
}

\begin{abstract}
:
We examine short selling around dividend announcements and ex-dividend dates. Contrary to our initial expectation, we do not find abnormally low (high) short-selling activity prior to announced dividend increases (decreases), which runs counter to the argument that short sellers have the ability to acquire private information before its public dissemination. However, we find that short selling prior to dividend announcements is less profitable than short selling during nonevent times, suggesting that information from dividend announcements is already incorporated into prices. Around ex-dividend dates, we do find abnormal short selling, which may be explained by the return pattern around ex-dividend days documented by Lakonishok and Vermaelen (1986), who suggest that demand for a particular stock by dividend capture traders drives stock prices above their fundamental value thus providing a profitable trading opportunity for short sellers. Consistent with this conjecture, we find that short selling on and after the exdividend day is more profitable as the negative relation between short selling and future returns is stronger on and after the ex-dividend day than during other times.
\end{abstract}




\section{Introduction}

Miller and Modigliani (1961) proposed that dividends are irrelevant. However, empiricists and theorists find that dividends and dividend changes may convey information to the market. ${ }^{1}$ In a separate stream of literature, Diamond and Verrecchia (1987) suggest that short sellers may be privately informed regarding a firm's true value. This paper combines these two ideas and examines short-selling activity around dividend announcements and ex-dividend days. The objective of our analysis is determine whether short sellers are able to acquire private information prior to negative announcements (Christophe, Ferri, and Angel, 2004) and whether short sellers attenuate the downward price movement on and after the ex-dividend date (Lakonishok and Vermaelen, 1986). Specifically, we test whether (i) abnormal short selling predicts negative news in dividend announcements, (ii) short selling prior to unfavorable dividend announcements is more profitable than short selling during non-event periods, (iii) short sellers target stocks with the greatest likelihood of a pre-ex-dividend price run up because of excess demand by dividend capture traders prior to the ex-dividend day, and (iv) whether exdividend return patterns provide unusual profitable trading opportunities to short sellers.

Our tests are motivated by two streams of research. First, Diamond and Verrecchia (1987) argue that negative returns will follow unanticipated increases in short selling. Empirical evidence favorably supports the Diamond and Verrecchia hypothesis as Senchack and Starks (1993), Aitken et al. (1998), Boehmer, Jones, and Zhang (2008), and Diether, Lee, and Werner (2009) find evidence that short-selling activity predicts future negative returns. Christophe, Ferri, and Angel (2004) find that short selling prior to unfavorable earnings relates negatively to

\footnotetext{
${ }^{1}$ See, for example, Miller and Modigliani (1961), Bhattacharya (1979), Aharony and Swary (1980), Asquith and Mullins (1983), Easterbrook (1984), John and Williams (1985), Michaely, Thaler, and Womack (1995), Miller and Rock (1985), Jensen (1986), and Lang and Litzenberger (1989).
} 
post-announcement returns, suggesting that short sellers have an ability to acquire private information before it is publicly observed. Recently, Chakrabarty and Shkilko (2008) and Karpoff and Lou (2008) find support of the idea that short sellers are able acquire private information about negative news before it becomes publicly available.

In additional tests of the Diamond and Verrecchia (1987) hypothesis, Boehmer and Wu (2008) show that short sales add to the informational efficiency in prices. When prices deviate from their true value, Boehmer and $\mathrm{Wu}$ show that informed investors execute short sales, thus reducing pricing errors and predicting price reversals. Combined with the results of Diether, Lee, and Werner (2009), who document that short sellers are generally contrarian in contemporaneous and past returns, the results of Boehmer and Wu suggest that short sellers target stocks that become out of line with their fundamental value and add to price efficiency by correcting shortterm, price overreaction.

The second stream of research that motivates our analyses suggests that dividends contain information about the future performance of the firm (i.e., dividends signal future earnings) or information about the perk consumption of management (i.e., dividends mitigate the free cash flow problem). One implication of this research is that changes in a firm's dividend policy should result in stock price changes in the same direction. Indeed, there is substantial empirical evidence of a direct relation between changes in stock prices and dividend changes. However, evidence is mixed as to whether the signaling or free cash flow hypothesis better explains why firms pay dividends. ${ }^{2}$ Regardless of which theory dominates, previous research concedes that dividends contain information about future firm performance. ${ }^{3}$ If dividend announcements

\footnotetext{
${ }^{2}$ See Allen and Michaely (2003).

${ }^{3}$ Fama and French (1998) find that dividends are informative. Similarly, Amihud and Murgia (1997) find that stock price reactions to dividends in Germany, a country where dividends are not tax-disadvantaged, are informative.
} 
contain information about the future performance of firms, and short sellers are able to acquire information before it is publicly observed, then we expect to find abnormal short selling prior to unfavorable dividend announcements.

The relation between trading behavior and dividend payments is not a new area of research (Kalay, 1982, Miller and Scholes, 1982, Lakonishok and Vermaelen, 1986, and Koski and Scruggs, 1998). Theory (Brennan, 1970, and Lakonishok and Vermaelen, 1986) suggests that some investors may prefer to avoid the double taxation of dividends while others may profit by capturing the dividend payment. ${ }^{4}$ Empirical results (Michaely and Vila, 1995, 1996, and Koski and Scruggs, 1998) find an increase in trading volume after the dividend announcement and before the ex-dividend date suggesting that some traders engage in dividend capture strategies. Lakonishok and Vermaelen (1986) show positive abnormal returns prior to the exdividend day and negative abnormal returns after, suggesting that increased (decreased) demand for dividend-paying stocks by dividend capture traders drives prices up prior to (after) the exdividend day. Lakonishok and Vermaelen show that ex-dividend return patterns are driven by stocks with larger dividend yields, which are likely stocks that generate the most demand by dividend capture traders. Koski and Scruggs (1998) find abnormal trading activity prior to the ex-dividend date. They conjecture that security dealers may short a stock cum-dividend and buy it back ex-dividend if they believe the price decrease on the ex-dividend date will be greater than the dividend paid. Therefore, we expect to find abnormal short selling around the ex-dividend

Brav, Graham, Harvey, and Michaely (2005) find that managers believe dividends do contain information but are not signaling in nature.

${ }^{4}$ Prior to 2003 dividends were taxed at a higher rate than capital gains, and investors in high tax brackets might have preferred to sell shares prior to the ex-dividend date to reduce their tax liability and repurchase them after the exdividend date. The dividend capture strategy suggests that traders will buy the stock cum-dividend and then sell the stock ex-dividend in attempt to capture the dividend income. 
date if short sellers seek to attenuate the downward price movement on and after the the exdividend date (Lakonishok and Vermalean, 1986).

Using a sample of 777 NYSE-listed firms that pay quarterly dividends during 2005 and 2006, we begin by analyzing short selling around dividend announcements. In order to test whether short sellers acquire the negative information contained in the upcoming dividend, we partition the data into dividend decreases (negative news) and dividend increases (positive news). We conjecture that abnormal short selling will occur prior to dividend decreases. However, we do not find such evidence. The lack of abnormal short selling suggests that either short sellers are not informed about unfavorable dividend announcements, or dividend announcements do not contain information about future firm performance and instead represents past performance that is already reflected in stock prices (Gonedes, 1978, and Benartzi, Michaely, and Thaler, 1997).

To further determine whether short sellers are uninformed or dividends are uninformative, we test whether the return predictability of is enhanced during the preannouncement period. We find that the usual negative relation between current short selling and future returns weakens during the pre-announcement period, suggesting that unfavorable dividend announcements present less profitable trading opportunities for short sellers than short selling during other times. Therefore, our results support the argument that dividend announcements do not provide important short-term information to short sellers about future firm performance.

Next, we examine trading around the ex-dividend day and find some abnormal shortselling activity in the days prior to the ex-dividend day. Our results support Koski and Scruggs' (1998) conjecture that some short sellers anticipate that the difference between the stock price 
cum-dividend and the price ex-dividend will be greater than the amount of the dividend plus any additional transaction costs. We also find abnormal short selling on and the few days after the ex-dividend day. This abnormal short-selling activity around the ex-dividend day is driven by stocks with larger dividend yields. This result supports the notion that short sellers seek to attenuate the downward price drift after the ex-dividend day (Lakonishok and Vermaelen, 1986). In addition, we determine whether short selling around the ex-dividend day is more profitable than short selling on other days. Our multivariate results show that the negative relation between current short selling and future returns is stronger around the ex-dividend day than during nonevent days. The observed negative relation is also strengthened by the size of the dividend yield, which is consistent with the notion that short sellers target stocks that have become overvalued because of excess demand by dividend capture trading.

The main contributions of our study are threefold. First, we provide new evidence showing relatively normal levels of short activity prior to unfavorable dividend announcements, which is initially inconsistent with the proposal of Christophe, Ferri, and Angel (2004), who argue that short sellers have an unusual ability to acquire private information. However, we show that short selling prior to dividend announcements is less profitable than during nonannouncement periods, suggesting that dividend announcements do not contain information regarding the future short-term prospects of the firm (Gonedes, 1978, and Benartzi, Michaely, and Thaler, 1997). Second, we show, consistent with Koski and Scruggs (1998), that some traders short stocks prior to the ex-dividend day because they believe that the difference between the price cum-dividend and the price ex-dividend is greater than the amount of the dividend and any additional transaction costs. Third, we provide new evidence of abnormal short selling on and after the ex-dividend day, which is driven by stocks with larger dividend yields. Further, 
tests reveal that this abnormal short selling is more profitable than short selling during non-event periods and that the profitability is directly related to the size of the dividend yield; a result consistent with the idea that short sellers attempt to profit from the anomalous return pattern around ex-dividend days described in Lakonishok and Vermaelen (1986).

The paper is organized as follows. Section II discusses the related research and develops our hypotheses. Section III describes our data. In Section IV, we present our empirical results while Section V concludes.

\section{Prior Research and Hypotheses}

Since Miller and Modigliani’s (1961) findings that under certain conditions, dividend policy is irrelevant to firm value, many arguments have been proposed to rationalize why dividends matter. Research concentrates on two hypotheses for why firms pay dividends: signal future earning or disburse free cash flow. The dividend-signaling hypothesis suggests that managers with better information than the market signal using dividends (Bhattacharya, 1979, John and Williams, 1985, and Miller and Rock, 1985). The free-cash flow hypothesis suggests that since managers cannot credibly pre-commit to not invest excess cash in negative-NPV projects, dividend changes can convey information about how the firm will use future cash flows (Pettit, 1972, Easterbrook, 1984, Jensen, 1986, and Lang and Litzenberger, 1989, and Nissam and Ziv, 2001) suggesting that dividend increases ensure less potential waste of free cash flow. The empirical implication from both hypotheses is that firms increasing (decreasing) dividends should evoke positive (negative) stock price reactions, and empirical tests confirm the reaction. 
As Allen and Michaely (2003) state, the evidence supporting the signaling hypothesis is weak at best. While dividend changes are associated with stock-price changes of the same sign around the dividend change announcement, Benartzi, Michaely, and Thaler (1997) show the relation between dividend changes and subsequent earnings changes are inconsistent with the theory. The evidence appears to favor the notion that dividends are related more strongly to past earnings than future earnings. ${ }^{5}$ Further, there is a significant price drift in subsequent years and, perhaps suggestive of the free cash flow hypothesis, the drift is driven by large and profitable firms, with less informational asymmetries, that pay most of the dividends.

Additional studies (Bernhardt, Douglas, and Robertson, 2005, Deshmukh, 2003, DeAngelo, DeAngelo, and Stulz, 2006, and Denis and Osobov, 2007) further document evidence inconsistent with the signaling theory while others (Grullon, Michaely and Swaminathan, 2002, Lie, 2000, Borokhovich, Brunarski, Harman, and Kehr, 2005, Rozeff, 1982, and Yoon and Starks, 1995) provide results counter to the free-cash flow argument. ${ }^{6}$ However, both theories have an underlying belief that dividends contain information. For instance, Fama and French (1998) find that dividends are informative while Amihud and Murgia (1997) find that stock price reactions to dividends in Germany, a country where dividends are not tax-disadvantaged, contain information. The consensus in the literature is that dividends contain information, although it is unclear what information is being conveyed. In this study, we are not concerned with what information is being conveyed by dividends, just that they do convey information.

\footnotetext{
${ }^{5}$ In addition to the contradictory evidence shown in Benartzi, Michaely, and Thaler (1997), Bernheim and Wantz (1995) argue that if dividend income is taxed more heavily, then the effect of the dividend signal on stock prices should be greater. They find evidence consistent with their argument. However, using data from 1978-1996, Bernhardt and Lee (2001) do not find that dividend taxes and signals are positively related. In addition, Brav, Graham, Harvey, and Michaely (2005) find that managers believe dividends do contain information but are not signaling in nature.

${ }^{6}$ Other theories suggest why firms pay dividends. Baker and Wurgler (2004) suggest that managers pay dividends to cater to investors demands. When investors place a premium on dividend paying (non-dividend paying) stocks, firms pay (omit) dividends. DeAngelo, DeAngelo, and Stulz (2006), Denis and Osobov (2007), and Blau and Fuller (2008) all suggest that dividend payments impact the financial flexibility of a firm.
} 
Recent research shows that short sellers have an unusual ability to acquire information prior to its public dissemination. Christophe, Ferri, and Angel (2004) find that abnormal short selling of stocks predicts negative post-earnings announcements return in the pre-announcement period. Similarly, Chakrabarty and Shkilko (2008) find abnormal short selling before the public release of insider sales while Karpoff and Lou (2008) report increasing short interest in the two years prior to public knowledge of firms charged with financial misconduct. If short sellers are able to acquire private information before it is publicly observed, we can test if dividend announcements contain information valuable to short sellers. The idea that dividend announcements contain information about the firm and short sellers obtain and trade on this information prior to announcement is referred to as the information acquisition hypothesis.

In a separate stream of literature, there is extensive research regarding the behavior of prices and volume around ex-dividend days. Early research focuses on whether investors value dividends less than capital gains. Elton and Gruber (1970) propose that the marginal investor is indifferent between buying and/or selling around the ex-dividend date. Thus, the price decrease on the ex-dividend day should reflect the difference in the tax rate for the marginal investors' capital gains and dividends. They find that price changes on the ex-dividend date are directly related with the dividend yield. However, Kalay (1982) and Miller and Scholes (1982) argue that short-term trading by exchange members or tax-exempt investors causes this relation. Extensive empirical tests of these two theories are not able to conclude whether tax-clienteles or short-term traders are the reason for this correlation. ${ }^{7}$

Lakonishok and Vermaelen (1986) suggest that it is difficult to distinguish between the tax-clientele and short-term trading hypotheses using only prices. They suggest that both prices

\footnotetext{
${ }^{7}$ See, for example, Elton and Gruber (1982), Eades, Hess, and Kim (1984, 1994), Karpoff and Walkling (1988, 1990), Michaely (1991), Koski (1996), and Bali and Hite (1998).
} 
and trading activity are needed to distinguish between the two theories. Their results show that trading volume increases significantly before and after the ex-dividend dates, and is higher for high yield stocks. Further, they find abnormal positive returns before the ex-dividend date and abnormal negative returns after the ex-dividend date, which, again, is driven by high yield stocks. They interpret these findings as short-term traders attempting to capture high dividendyield payments. ${ }^{8}$ Koski and Scruggs (1998) try to distinguish whether the observed increase in trading volume is attributable to securities dealers or to corporations. Security dealers will attempt to profit on the difference between the expected capital loss and the dividend. Due to their low transactions costs, dealers will buy (sell) the stock cum-dividend and sell (buy) it exdividend, if the price decrease on the ex-dividend date is less (greater) than the dividend. Since corporations face lower tax rates on dividends received from other corporations than on capital gains, corporations may trade to capture the dividends paid by other corporations. Koski and Scruggs find strong evidence that securities dealers engage in dividend capture strategies and weaker evidence that corporations do. ${ }^{9}$ We investigate short sellers' response to the return pattern surrounding the ex-dividend day. If demand from dividend capture traders drives run up stock prices prior to the ex-dividend date, then sophisticated investors will likely short the stocks on and after the ex-dividend date to assist in the attenuation of the documented downward price movements (Lakonishok and Vermaelen, 1986).

Recently, Boehmer and Wu (2008) show that short sellers assist in correcting mispriced stocks. At the daily level, the authors report that short selling reduces pricing errors and thus, adds to the informational efficiency in prices. In the same spirit, Diether, Lee, and Werner

\footnotetext{
${ }^{8}$ Michaely and Vila $(1995,1996)$ show dividend yields and tax heterogeneity increase the ex-dividend trading volume while risk and transactions costs reduce the volume.

${ }^{9}$ Graham and Kumar (2006) also document a type of dividend clientele trading. They find that older, lower income investors tend to purchase stocks following dividend announcements and before the ex-dividend date to capture the dividend income.
} 
(2009) report that short sellers are contrarian in contemporaneous and past returns and have the ability to predict negative returns, suggesting that short sellers successfully target overvalued stocks and are able to consistently predict price reversals. If short sellers attempt to profit on the anomalous return pattern around ex-dividend dates, then we expect short-selling activity to increase around these days. We refer to abnormal short selling surrounding the ex-dividend day as the price run up hypothesis.

The motivation for short selling under our two hypotheses is shown in Figure 1. Short selling prior to dividend announcements is motivated by information contained in the dividend announcement (information acquisition hypothesis) while short selling after the announcement and around the ex-dividend day is motivated by excess demand from dividend capture trading (overvaluation hypothesis).

\section{Data Description}

In January 2005, the Securities and Exchange Commission mandated that short-sale transactions data be made available under regulation SHO. From the SHO data we calculate the amount of daily short volume. From the Center for Research in Security Prices (CRSP), we obtain volume, market capitalization, shares outstanding, prices, and returns. We limit our sample to ordinary common stocks (CRSP share code 10 or 11) that are listed on the NYSE between January 2005 and December 2006. We require stocks in our sample to be traded every day of the sample time period and have a price greater than $\$ 2$. From CRSP we collect a sample of firms paying quarterly dividends between January 2005 and December 2006. After merging the SHO data with the CRSP data, our final sample contains 777 NYSE-listed stocks with a total of 5,090 dividend payments. 
Table 1 reports statistics that describe the sample. Panel A reports characteristics of our sample. The average stock has a market capitalization of nearly $\$ 1.2$ billion and a price of $\$ 41$. We calculate two different measures of volatility. Return volatility is the standard deviation of daily returns from day $t-10$ to $t$, where day $t$ is the current trading day. Following Diether, Lee, and Werner (2009), we calculate price volatility by dividing the difference between the daily high price and the daily low price by the daily high price. The average stock has a return and price volatility of 1.5 percent and 2 percent, respectively. Panel B reports trading characteristics for our sample. From CRSP, we calculate the share turnover as the daily volume divided by the number of shares outstanding. We also obtain the short turnover by dividing the daily short volume by the number of shares outstanding.

Following previous studies (Christophe, Ferri, and Angel, 2004, Diether, Lee, and Werner, 2009, and Boehmer, Jones, and Zhang, 2008), we calculate the short ratio, which is the ratio of short volume to trade volume. We find that the average stock in our sample has a share turnover of 0.71 percent, short turnover of 0.16 percent, and a daily short volume of nearly 238,000 shares. The average short ratio is slightly over 22 percent, which is consistent with Diether, Lee, and Werner (2009), who find that short sales make up 24 percent of trade volume for a broad cross section of NYSE stocks.

In Panel $\mathrm{C}$, we report characteristics about the dividends in our sample. The average dividend paid is nearly 19 cents a share, with a yield of approximately 0.5 percent. We also report the average amount of a dividend increase is 3.5 cents and the average dividend decrease is 11.4 cents. 


\section{Results}

This section provides tests of the hypotheses we develop in Section II. We first test the information acquisition hypothesis, which suggests that short sellers are informed about the information contained in upcoming dividend announcements that will result in an abnormal decrease (increase) in short selling prior to the announcement of a dividend increase (decrease). Next, we test the price run up hypothesis, which implies that short sellers will target similar stocks as dividend capture traders in attempt to profit from the return pattern around the exdividend day.

\section{IV.A Informed Announcements}

We begin testing the information acquisition hypothesis using a standard event study. Since we want to isolate trading around the dividend announcement, we examine a 21-day window around the event. We standardize the short ratio and short turnover using the following equation:

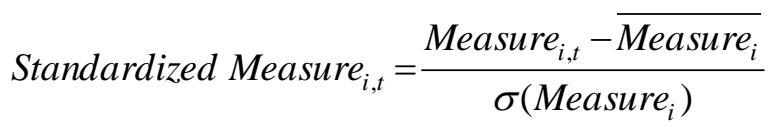

where Measure $_{i, \mathrm{t}}$ is the short-selling measure for stock $i$ on day $t, \overline{\text { Measure }_{i}}$ is the average amount of short selling for stock $i$ across the sample time period, and $\sigma\left(\right.$ Measure $\left._{i}\right)$ is the standard deviation in daily short selling for stock $i$. The standardization procedure is similar to Lakonishok and Vermaelen (1986), Koski and Scruggs (1998), and Sias (2004) and allows the short-selling measure for each stock on each day to be similarly distributed with a zero mean and 
a unit variance. We report the results of $t$-tests that determine whether short selling is abnormally different from zero for each day in the event window. ${ }^{10}$

Table 2 reports the results of an event study around dividend announcements. Column (1) reports the market-adjusted returns for each day. Columns (2) and (3) show the short ratio and standardized short ratio, respectively. We do not find significantly more or less short selling activity prior to and on the announcement date. We do find abnormal short selling from day $t-10$ to $t-8$ as well as on day $t+1$ and day $t+2$. However, short selling appears relatively normal prior to dividend announcements. When examining the standardized short turnover, we find some evidence of increased short selling in the four days prior to an announcement. However, these results seem to lack economic significance as short turnover appears relatively constant prior to the announcement and substantially increases on the announcement day and four days after the announcement. By day $t+1$, short turnover is 23.5 percent higher than the average preannouncement short turnover.

Next, we partition our sample into dividend increase announcements (positive news) and dividend decrease announcements (negative news). Table 3 Panel A reports the results for dividend increases. The information acquisition hypothesis suggests that abnormally low short selling will occur prior to the announcement of a dividend increase. Though we show daily returns are positive on the announcement day and the day after the announcement, there is not significantly low short selling prior to announced dividend increases. On day $t-4$ the standardized short ratio is significantly negative; however, the short turnover ratio is insignificant. Interestingly, there is abnormally high short selling on the announcement day and the week after the announcement, perhaps suggesting that short sellers believe that the market

\footnotetext{
${ }^{10}$ We also use a standard event study method by taking the difference between the daily measure and a benchmark [ $t$-30 to $t-11]$. Results using this different benchmark are qualitatively similar with the results we report using the methods of Lakonishok and Vermaelen (1986), Koski and Scruggs (1998), and Sias (2004).
} 
has overreacted to the good information in the dividend announcement. Overall, the results suggest that dividend increases do not contain a great deal of new information.

Panel B reports the results for dividend decreases. The information acquisition hypothesis predicts that short sellers are informed about the upcoming dividend decrease and we should therefore observe abnormally high short-selling activity prior to the dividend decrease announcement. We find announcement-day returns are significantly negative, but we do not show abnormal short selling prior to the dividend decrease. The standardized short turnover is positive the day before the announcement, although only marginally significant at the 10 percent level. Similar to the results in Panel A, we show a significant increase in short turnover after the announcement. Again, the finding suggests that short sellers react rather than predict the bad news in dividend announcements as short turnover is nearly 55 percent higher on day $t+1$ than on day $t-1$.

These results do not support the information acquisition hypothesis and suggest that short sellers are not able to acquire information about upcoming dividend announcements. ${ }^{11}$ However, a closer examination of Table 3 Panel B reveals that while prices adjust downward on the announcement day of a dividend decrease, on day $t+1$, returns become significantly positive (0.66 percent). An observed increase in prices in the few days after an unfavorable dividend announcement suggests that dividend announcements may not contain information about future firm performance and instead reflect past information (Gonedes, 1978, and Benartzi, Michaely, and Thaler, 1997). We provide indirect tests of this conjecture next.

\footnotetext{
${ }^{11}$ Since researchers (Asquith and Mullins, 1983, and Miller and Rock, 1985) suggest that the larger the dividend change, the larger the potential informational content of the dividend, we partitioned our dividend increase sample and dividend decrease sample by dividend yield and examined if there was significantly more short selling for large dividend decreases or significantly less short selling for large dividend increases. We did not find any indication that short sellers traded significantly more or less when firms had larger dividend decreases or increases. The results are available upon request.
} 
Given there are several factors that influence the level of short selling, we provide additional tests in a multivariate setting. Combining the methods of Christophe, Ferri, and Angel (2004) and Diether, Lee, and Werner (2009), we estimate the following equation using pooled data.

$$
\begin{aligned}
s h \_ \text {sell }_{i, t-5, t-1}= & \beta_{0}+\beta_{1} \text { turn }_{i, t-5, t-1}+\beta_{2} \text { pvolt }_{i, t-5, t-1}+\beta_{3} \text { size }_{i, t}+\beta_{4} \text { sh_sell }_{i, t-10, t-6}+\beta_{5} \text { ret }_{i, t-5, t-1}+\beta_{6} \text { ret }_{i, t-} \\
& 10, t-6+\beta_{7} \text { ret }_{i, t, t+2}+\beta_{8} D I V \Delta_{t}+\beta_{9} \text { ret }_{i t, t+2} \times D I V \Delta_{t}+\varepsilon_{i, t-5, t-1}
\end{aligned}
$$

where $s h_{-} s e l l_{i, t-5, t-1}$ is the short-selling measure for firm $i$ for day $t-5$ to day $t-1$, turn $_{i, t-5, t-1}$ is the share turnover for firm $i$ for day $t-5$ to day $t-1, p v o l t_{i, t-5, t-1}$ is the price volatility for firm $i$ for day $t-5$ to day $t-1$, size $_{i, t}$ is the market capitalization in $\$$ billions for firm $i$ on day $t, s h \_s e l l_{i, t-10, t-6}$ is the lagged short-selling measure for firm $i$ for day $t-10$ to day $t-6$, ret $_{i, t-10, t-6}$ is cumulative return for firm $i$ from day $t-10$ to day $t-6$, ret $_{i, t-5, t-1}$ is the contemporaneous cumulative return for firm $i$ from day $t-5$ to day $t-1$, ret $_{i, t, t+2}$ is the cumulative return for firm $i$ from day $t$ to day $t+2, D I V \Delta_{t}$ (where $D I V \Delta$ is either INC or DEC for increase or decrease) is a dummy variable equal to one if day $t$ is a dividend increase (decrease) announcement day and 0 otherwise, and $r e t_{i, t, t+2} \times D I V \Delta_{t}$ is the interaction of future returns and the announced dividend-change day dummy, and all other variables are as previously defined. For dividend increases (decreases) we expect the estimate for the dummy to be negative (positive). If short sellers are able to acquire private information before its public release then we anticipate abnormal short selling prior to an announced dividend decrease. We include the interaction variable to further test for an explanation for the lack of evidence supporting the information acquisition hypothesis. If the return predictability of short sellers is enhanced prior to announced dividend changes, then the interaction estimate will be negative. 
Table 4 reports the results of estimating equation (2). A Hausman test rejects the presence of random effects. However, we observe differences across stocks and days so we control for stock and day fixed effects. ${ }^{12}$ Columns (1) through (3) show that results using the short ratio as the short-selling measure while columns (4) through (6) report the results using short turnover. Consistent with Diether, Lee, and Werner (2009) we find that turnover (price volatility) is negatively (positively) related to the short ratio. We also find that size is positively related the short selling, which is consistent with Arnold et al. (2005). We show that short sellers are contrarian in contemporaneous and past returns and are able to predict future negative returns (Diether, Lee, and Werner, 2009). We do find some evidence for the information acquisition hypothesis as the estimate for the dummy variable $I N C$ is negative and significant when using the short ratio as the dependent variable. However, the result is not robust to the alternative short-selling measure as the estimate is insignificant when using the short turnover for the dependent variable. For both measures of short selling, we find that the interaction of future returns and the dummy variable $I N C$ insignificantly different from zero. When estimating equation (3) for dividend decreases, the estimate for the dummy $D E C$ is insignificant, suggesting that there is no abnormal short selling prior to dividend decrease announcements. Together, these results again contradict the information acquisition hypothesis. Interestingly, the interaction between future returns and the dummy variable $D E C$ is significantly positive in column (8), suggesting that short selling may be less profitable prior to announced dividend decreases. This positive interaction estimate provides a possible explanation for why there is no abnormal short selling prior to dividend decrease announcements; Short selling prior to unfavorable announcements is less profitable than usual. Consistent with prior research, we conclude that

\footnotetext{
${ }^{12}$ Our results are qualitatively similar when controlling for conditional heteroskedasticity and clustering in errors.
} 
short sellers do not believe that dividend announcements provide a valuable signal of short-term future firm performance and may, instead, contain past information.

\section{B Excess Demand from Dividend Capture Trading}

Next, we test the overvaluation hypothesis which suggests that abnormal short selling will occur around the ex-dividend day for stocks that are overvalued because of excess demand from dividend capture trading. We report market-adjusted returns and different measures of short selling for a 21-day window around ex-dividend days. Table 5 shows that abnormal returns on the ex-dividend day and negative abnormal returns occur in days $t+5$ and day $t+6$. We find an abnormally high short ratio on the ex-dividend day and a few days after the ex-dividend day. When examining the short turnover, we find abnormal short selling prior to the ex-dividend day. The latter findings are consistent with Koski and Scruggs (1998), who suggest that some investors may choose to short stocks before the ex-dividend day if the price cum-dividend and the price ex-dividend are greater than the amount of the dividend and any additional transaction costs. From day $t$ to day $t+3$, short turnover is also abnormally high. Lakonishok and Vermaelen (1986), Eades, Hess, and Kim (1994), and Naranjo, Nimalendran, and Ryngaert (2000) document that prices decrease after the ex-dividend day. Thus are our results are consistent with the price run up hypothesis, which suggests that short sellers attenuate the adjustment of prices after the ex-dividend day.

Consistent with the notion of dividend capture trading, Lakonishok and Vermaelen (1986) find that price increases prior to the ex-dividend day and subsequent price decreases after the ex-dividend day are driven by the size of the dividend yield. In Table 6, we sort our sample of stocks into quartiles based on the size of the dividend yield. Table 6 shows that cumulative 
returns from day $t-5$ to day $t-1$ are monotonically increasing across dividend yield quartiles, with the largest dividend yields having the largest abnormal returns prior to the ex-dividend day. These results suggest that dividend capture trading is driven by the size of the dividend yield (Lakonishok and Vermaelen, 1986).

Table 7 reports the event study for both the short ratio (Panel A) and short turnover (Panel B) by quartile. Panel A shows that abnormal short selling on and after the ex-dividend day is driven by stocks with the largest dividend yields. For Quartile I, we observe abnormally low short selling on the ex-dividend day. In Quartile II, we do not find unusually high shortselling activity around the ex-dividend day. However, in Quartiles III and IV, we find evidence of increasing short selling around the ex-dividend day indicating that higher dividend yields drive the abnormal short selling from day $t$ to day $t+3$. This finding is consistent with the idea that stocks with the largest dividend yields attract the most dividend capture trading and result in the most distinct ex-dividend day return pattern.

The results in Panel B are generally consistent with those in Panel A, as abnormal short selling on the ex-dividend day is driven by short selling of stocks with larger dividend yields in Quartiles III and IV. Interestingly, we find that the standardized short turnover if monotonically increasing across increases quartiles on the ex-dividend day suggesting that short sellers recognize the potential overvaluation caused by dividend capture traders.

Again, other factors may influence the level of short selling so we test the overvaluation hypothesis in a multivariate setting. We estimate the following equation.

$$
\begin{gathered}
{\operatorname{sh} \_s e l l_{i, t, t+4}}=\beta_{0}+\beta_{1} \text { turn }_{i, t, t+4}+\beta_{2} \text { pvolt }_{i, t, t+4}+\beta_{3} \text { size }_{i, t}+\beta_{4} \text { sh_sell }_{i, t-5, t-1}+\beta_{5} \text { ret }_{i, t, t+4}+\beta_{6} \text { ret }_{i, t-5, t-1}+ \\
\beta_{7} \text { ret }_{i, t+5, t+7}+\beta_{8} E X_{t} \text { or EX }(+)_{t}+\beta_{9} \operatorname{ret}_{i, t+5, t+7} \times E X_{t} \text { or EX }(+)_{t}+\varepsilon_{i, t, t+4}
\end{gathered}
$$


Where the dependent variables are the short ratio and short turnover for the specified time period (day $t$ to day $t+4$ ), $E X_{t}$ is a dummy variable equal to one if day $t$ is the ex-dividend day and zero otherwise, $E X(+)_{t}$ is equal the size of the dividend yield if day $t$ is an ex-dividend day and zero otherwise, ret $_{i, t+5, t+7} \times E X_{t}$ is the interaction of future returns and the ex-dividend day dummy, and all other variables are as previously defined. We also interact $E X$ and $E X(+)$ with future returns in order to test if short selling on, and after the ex-dividend day is more profitable than during non-event periods. A positive estimate for $E X$ is consistent with price run up hypothesis. Similarly, a positive estimate for $E X(+)$ implies that the level of short selling on and after the exdividend day is driven by the dividend yield, which motivates greater dividend capture trading (Lakonishok and Vermaelen, 1986). Negative estimates for the interaction variables indicate that the common negative relation between current short selling and future returns is stronger than usual on and just after the ex-dividend day.

Table 8 reports the results of estimating equation (4) controlling for stock and day fixed effects. We find that short sellers are able to predict negative returns as the estimate for ret $_{i, t+5, t+7}$ is significantly negative. Further, the estimate for the dummy variable $E X$ is positive and significant in columns (1), (2), (5), and (6), thus supporting the overvaluation hypothesis. When interacting the dummy variable $E X$ with future returns, the estimate is negative indicating that short selling on and after ex-dividend day is more profitable than short selling during more normal times.

When examining the relation between short selling and the variable $E X(+)$, we find evidence that the abnormal short ratio is driven by size of the dividend yield as the estimate is positive and significant $(p$-value $=0.054)$. However, we do not find a significant positive estimate for $E X(+)$ in the short turnover regressions. When interacting $E X(+)$ with future 
returns, we find strong support for the price run up hypothesis as the interaction estimate is significantly negative, suggesting that the profitability of short selling on and after the exdividend day is increasing in the size of the dividend yield. Combined with the results for the interaction of the dummy variable $E X$ and future returns, the negative interaction estimate for $E X(+)$ and future returns suggests that short selling on and after the ex-dividend day is more profitable than during non-event times and the profitability is driven by the size of the dividend yield.

\section{Conclusion}

We investigate short-selling activity around dividend announcements and ex-dividend dates. Following a stream of literature that finds that short sellers are able to acquire private information before its public dissemination, we hypothesize that short selling will be abnormally high (low) prior to dividend decreases (increases). Contrary to our hypothesis, we do not find significant abnormal short selling in the pre-announcement period. This result suggests that either short sellers are not able to acquire information about upcoming dividend announcements or announcements do not reflect information that has yet to impact prices.

We test whether the negative relation between current short selling and future returns is stronger during the period prior to unfavorable dividend announcements than during non-event

periods. Interestingly, we show that short sellers are less able to predict negative returns prior to unfavorable announcements than during non-event times, suggesting that short selling during the pre-announcement period is less profitable than short selling during non-event periods. Therefore, we conclude that short sellers do not believe that dividend announcements contain 
information about the future short-term performance of the firm but instead reflect past information that is already incorporated in prices.

While Lakonishok and Vermaelen (1986) show that stock prices increase prior to and decrease after the ex-dividend day, we examine whether short sellers attempt to profit from the documented return pattern by assisting in the attenuation of the downward price drift. We find some evidence of abnormal short selling in the days prior to the ex-dividend date, thus supporting the argument of Koski and Scruggs (1998) that some traders attempt to profit on the difference in the price drop and the dividend amount. We also find abnormal short selling on and after the ex-dividend date, which is driven by the short selling of stocks with larger dividend yields. The latter finding suggests that short sellers recognize that larger yields may attract greater demand from capture strategists (Lakonishok and Vermaelen, 1986), which may drive the ex-dividend return pattern. Consistent with our argument, we show that short selling on and after the ex-dividend day is more profitable than normal as the negative relation between current short selling and future returns is stronger on and after the ex-dividend day than during other times. Further, the stronger negative relation between short selling and future returns on and after the ex-dividend day is enhanced by the size of the dividend yield. Our findings imply that while dividend announcements do not provide profitable trading opportunities for short sellers, exdividend days may. 


\section{References}

Aharony, J., and I. Swary, 1980, “Quarterly Dividend and Earning Announcements and Stockholders' Returns: An Empirical Analysis.” Journal of Finance 35, 1-12.

Aitken, M., A. Frino, M. McCorry, and P. Swan, 1998, "Short Sales are Almost Instantaneously Bad News: Evidence from the Australian Stock Exchange.” Journal of Finance 53, 2205-2223.

Allen, F., and R. Michaely, 2003, "Payout Policy” in George Constantinides, Milton Harris, and Rene Stulz edition. Handbook of Economics, (North-Holland).

Amihud, Y., and M. Murgia, 1997, "Dividends, Taxes, and Signaling: Evidence from Germany." Journal of Finance 52, 397-408.

Asquith, P., and D. Mullins, 1983, "The Impact of Initiating Dividend Payments on Shareholders' Wealth.” Journal of Business 56, 77-96.

Arnold, T., A.W. Butler, T.F. Crack, and Y. Zhang, 2005, "The Information Content of Short Interest: A Natural Experiment.” Journal of Business 78, 1307-1335.

Asquith, P., and D.W. Mullins, Jr., 1983, "The Impact of Initiating Dividend Payments on Shareholders' Wealth.” Journal of Business 56, 77-96.

Baker, M., and J. Wurgler, 2004, "A Catering Theory of Dividends," Journal of Finance 59, 11251165.

Bali, R., and G.L. Hite, 1998, "Ex-Dividend Day Stock Price Behavior: Discreteness or TaxInduced Clienteles?” Journal of Financial Economics 47, 127-159.

Benartzi, S., R. Michaely, and R. Thaler, 1997, "Do Changes in Dividends Signal the Future of the Past?" The Journal of Finance 52, 3, 1007-1034.

Bernhardt, D., A. Douglas, and F. Robertson, 2005, "Testing Dividend Signaling Models." Journal of Empirical Finance 12, 77-98.

Bernhardt, D., and T. Lee, 2001, “Dividend Signaling: Fact or Fiction?” Working paper, University of Illinois.

Bernheim, B.D. and A. Wantz, 1995, "A Tax-based Test of the Dividend Signaling Hypothesis," American Economic Review 85, 532-551.

Bhattacharya, S., 1979, "Imperfect Information, Dividend Policy, and 'The Bird in the Hand' Fallacy." Bell Journal of Economics 10, 259-270.

Blau, B.M., and K.P. Fuller, 2008, "Flexibility and Dividends.” Journal of Corporate Finance 14, 133-152. 
Boehmer E., C.M. Jones, and X. Zhang, 2007, "Which Shorts are Informed?" Journal of Finance 63, 491-527.

Boehmer, E., and J. Wu, 2008, "Short Selling and the Informational Efficiency of Prices." Working paper, University of Georgia.

Borokhovich, K.A., K.R. Brunarski, Y. Harman, and J.B. Kehr, 2005, "Dividends, Corporate Monitors, and Agency Costs.” Financial Review 40, 57-65.

Brav, A., J.R. Graham, C.R. Harvey, and R. Michaely, 2005, "Payout Policy in the $21^{\text {st }}$ Century." Journal of Financial Economics 77, 483-527.

Brennan, M., 1970, “Taxes, Market Valuation, and Financial Policy.” National Tax Journal 23, 417-429.

Chakrabarty, B., and A. Shkilko, 2008, "Selective Information Leakages in Financial Markets: Evidence from Shorting Around Insider Sales.” Working Paper, Wilfred Laurier University.

Christophe, S., M. Ferri, and J. Angel, 2004, "Short Selling Prior to Earnings Announcements." Journal of Finance 59, 1845-1875.

DeAngelo, H., L. DeAngelo, and R. Stulz, 2006, "Dividend Policy and the Earned/Contributed Capital Mix: A Test of the Life-Cycle Theory." Journal of Financial Economics 81, 227-254.

Denis, D.J., and I. Osobov, 2007, "Why Do Firms Pay Dividends? International Evidence on the Determinants of Dividend Policy." forthcoming Journal of Financial Economics.

Deshmukh, S., 2003, "Dividend Initiations and Asymmetric Information: A Hazard Model." Financial Review 38, 351-368.

Diamond, D., and R. Verrecchia, 1987, "Constraints on Short selling and Asset Price Adjustment to Private Information.” Journal of Financial Economics 18, 277-312.

Diether, K.B., K.H. Lee and I.M. Werner, 2009, “Can Short-Sellers Predict Returns? Daily Evidence.” Review of Financial Studies 22, 575-607.

Eades, K.M., P.J. Hess, and E.H. Kim, 1984, “On Interpreting Security Returns during the ExDividend Period." Journal of Financial Economics 13, 3-34.

Eades, K.M., P.J. Hess, and E.H. Kim, 1994, "Time-Series Variation in Dividend Pricing.” The Journal of Finance 49, 1617-1638.

Easterbrook, F., 1984, “Two Agency-cost Explanations of Dividends." American Economic Review 74, 650-659. 
Elton, E.J., and M.J. Gruber, 1970, "Marginal Stockholder Tax Rates and the Clientele Effect." Review of Economics and Statistics 52, 68-74.

Elton, E.J., and M.J. Gruber, 1982, “The Ex-Dividend Day Behavior of Stock Returns:

Further Evidence on Tax Effects." Journal of Finance 37, 445-456.

Fama, E. F., and K. R. French, 1998, “Taxes, Financing Decisions, and Firm Value.” Journal of Finance 53, 3, 819-843.

Gonedes, N.J., 1978, “Corporate Signaling, External Accounting, and Capital Market Equity: Evidence on Dividends, Income, and Extraordinary Items." Journal of Accounting Research 16, 26-79.

Graham, J., and A. Kumar, 2006, "Do Dividend Clienteles Exist? Evidence on Dividend Preferences of Retail Investors." Journal of Finance 61, 1305-1336.

Grullon, G., R. Michaely, and B. Swaminathan, 2002, “Are Dividend Changes a Sign of Firm Maturity?" Journal of Business 75, 387-424.

Jensen, M., 1986, "Agency Costs of Free Cash Flow, Corporate Finance, and Takeovers." American Economic Review 76, 323-329.

John, K., and J. Williams, 1985, "Dividends, Dilution, and Taxes: a Signaling Equilibrium." Journal of Finance 40, 1053-1070.

Kalay, A., 1982, "The Ex-Dividend Day Behavior of Stock Price: A Reexamination of the Clientele Effect." Journal of Finance 37, 1059-1070.

Karpoff, J.M., and X. Lou, 2008, "Do Short Sellers Detect Overpriced Firms? Evidence from SEC Enforcement Actions." Working Paper, University of Washington.

Karpoff, J.M., and R.A. Walking, 1988, "Short-Term Trading around Ex-Dividend Days: Additional Evidence." Journal of Financial Economics 21, 291-298.

Karpoff, J.M., and R.A. Walking, 1990, "Dividend Capture in NASDAQ Stocks." Journal of Financial Economics 28, 39-66.

Koski, J.L., 1996, “A Microstructure Analysis of Ex-Dividend Stock Price Behavior Before and After the 1984 and 1986 Tax Reform Acts.” Journal of Business 69, 313-338.

Koski, J.L., and J.T. Scruggs, 1998, "Who Trades Around the Ex-Dividend Day? Evidence from NYSE Audit File Data." Financial Management 27, 3, 58-72.

Lakonishok, J., and T. Vermaelen, 1986, "Tax-Induced Trading Around Ex-dividend Days." Journal of Financial Economics 3, 287-319. 
Lang, L., and R. Litzenberger, 1989, “Dividend Announcements: Cash Flow Signaling vs. Free Cash Flow Hypothesis?” Journal of Financial Economics 24, 181-192.

Lie, E., "Excess Funds and Agency Problems: An Empirical Study of Incremental Cash Disbursements." Review of Financial Studies 13, 219-248.

Michaely, R., 1991, "Ex-Dividend Day Stock Price Behavior: The Case of the 1986 Tax Reform Act." Journal of Finance 46, 845-859.

Michaely, R., R.H. Thaler, and K.Womack, 1995, "Price Reactions to Dividend Initiations and Omissions: Overreaction or Drift?” Journal of Finance 50, 573-608.

Michaely, R., and J.L. Vila, 1995, "Investors' Heterogeneity, Prices, and Volume Around the Ex-Dividend Day.” Journal of Financial and Quantitative Analysis 30, 171-198.

Michaely, R., and J.L. Vila, 1996, "Trading Volume with Private Valuation: Evidence from the Ex-Dividend Day.” Review of Financial Studies 9, 471-509.

Miller, M., and F. Modigliani, 1961, "Dividend Policy, Growth, and the Valuation of Shares." Journal of Business 34, 411-433.

Miller, M., and K. Rock, 1985, "Dividend Policy under Asymmetric Information.” Journal of Finance 40, 1031-1051.

Miller, M., and M. Scholes, 1982, “Dividends and Taxes: Some Empirical Evidence.” Journal of Political Economy 90, 1118-1141.

Naranjo, A., M. Nimalendran, and M. Ryngaert, 2000, “Time Variation of Ex-dividend Day Stock Returns and Corporate Dividend Capture: A Reexamination.” Journal of Finance 55, 2357-2372.

Nissam, D., and A. Ziv, 2001, "Dividend Changes and Future Profitability." Journal of Finance 56, 2111-2133.

Pettit, R.R., 1972, "Dividend Announcements Security Performance, and Capital Markets." Journal of Finance 27, 993-1007.

Rozeff, M.S., 1982, "Growth, Beta, and Agency Costs as Determinants of Dividend Payout Ratios.” Journal of Financial Research 5, 249-259.

Senchack, A. J., and L.T. Starks, 1993, "Short-sale Restrictions and Market Reaction to ShortInterest Announcements." Journal of Financial and Quantitative Analysis 28, 177-194.

Sias, R.W., 2004, “Institutional Herding.” Review of Financial Studies 17, 165-206.

Watts, R., 1973, “The Information Content of Dividends.” Journal of Business 46, 191-211. 
Yoon, P., and L. Starks, 1995. "Signaling, Investment Opportunities, and Dividend Announcements." Review of Financial Studies 8, 995-1018. 
Table 1

Summary Statistics

The table presents statistics that describe the sample. Panel A reports following stock characteristics. Market capitalization is the CRSP market cap in (000s). Price is the daily closing price. Return volatility is the standard deviation of daily returns from day $t-10$ to day $t$, where day $t$ is the current trading day. Price volatility is the difference between the daily high price and the daily low price divided by the daily high price. Panel B reports the following trading statistics. Share turnover is the daily trade volume divided by the shares outstanding. Short volume is the daily number of shares that are shorted. Short turnover is the daily short volume divided by the number of shares outstanding. Short ratio is the daily short volume divided by the daily trade volume. Panel $\mathrm{C}$ reports statistics about the dividends. The amount of the dividend and the dividend yield are reported along with the amount of dividend changes. Increases (decreases) are the positive (negative) difference between the current dividend and the last dividend paid.

\begin{tabular}{|c|c|c|c|c|}
\hline \multicolumn{5}{|c|}{ Panel A. Stock Characteristics } \\
\hline & $\begin{array}{c}\text { Market } \\
\text { Capitalization }\end{array}$ & Price & Return Volatility & Price Volatility \\
\hline Mean & $1,175,013$ & 41.27 & 0.0152 & 0.0203 \\
\hline Std. Deviation & $30,739,193$ & 36.09 & 0.0051 & 0.0065 \\
\hline $\operatorname{Min}$ & 76,251 & 5.04 & 0.0068 & 0.0099 \\
\hline $\operatorname{Max}$ & $381,428,053$ & 796.82 & 0.0361 & 0.0461 \\
\hline \multicolumn{5}{|c|}{ Panel B. Trading Characteristics } \\
\hline & Share Turnover & Short Volume & Short Turnover & Short Ratio \\
\hline Mean & 0.0071 & $237,551.48$ & 0.0016 & 0.2217 \\
\hline Std. Deviation & 0.0049 & $362,413.40$ & 0.0014 & 0.0633 \\
\hline Min & 0.0003 & 898.01 & 0.0000 & 0.0958 \\
\hline $\operatorname{Max}$ & 0.0391 & $3,387,466.27$ & 0.0202 & 0.6363 \\
\hline \multicolumn{5}{|c|}{ Panel C. Dividend Characteristics } \\
\hline & Dividend Paid & Dividend Yield & Increases & Decreases \\
\hline Mean & 0.1871 & 0.0051 & 0.0355 & -0.1143 \\
\hline Std. Deviation & 0.1682 & 0.0037 & 0.0746 & 0.01514 \\
\hline $\operatorname{Min}$ & 0.0040 & 0.0001 & 0.0010 & -1.3350 \\
\hline $\operatorname{Max}$ & 1.9994 & 0.0298 & 1.1280 & -0.0050 \\
\hline$N$ & 5,090 & 5,090 & 840 & 139 \\
\hline
\end{tabular}


Table 2

Event Study around Dividend Announcements

The table present results from a standard event study around dividend announcements. Market-adjusted returns and the CRSP raw returns less the CRSP equally-weighted index. The short ratio (daily short volume divided by the daily trade volume) and the short turnover (daily short volume divided by the number of shares outstanding) are reported along with standardized measures of short selling. In order to standardize the short selling measures, we divide the difference between the short measure for stock $i$ on day $t$ and the average short measure for stock $i$ by the standard deviation of the short measure for stock $i$. The standardization procedure allows each stock to have a short measure on each day that is similarly distributed with a zero mean and a unit variance. Results from $t$-tests are reported using asterisks. The $t$ test tests whether the standardized short measure is significantly different from zero.

\begin{tabular}{|c|c|c|c|c|c|}
\hline & $\begin{array}{c}\text { Market-Adj. } \\
\text { Returns }\end{array}$ & Short Ratio & $\begin{array}{l}\text { Standardized } \\
\text { Short Ratio }\end{array}$ & Short Turn & $\begin{array}{l}\text { Standardized } \\
\text { Short Turn }\end{array}$ \\
\hline$t-10$ & -0.0002 & 0.2263 & $0.0419 * * *$ & 0.0017 & 0.0190 \\
\hline$t-9$ & $-0.0006^{* * *}$ & 0.2260 & $0.0406 * * *$ & 0.0017 & 0.0041 \\
\hline$t-8$ & 0.0000 & 0.2256 & $0.0334 * *$ & 0.0016 & $-0.0238^{* *}$ \\
\hline$t-7$ & 0.0002 & 0.2217 & 0.0010 & 0.0017 & $-0.0266^{* *}$ \\
\hline$t-6$ & $0.0009 * * *$ & 0.2207 & -0.0031 & 0.0017 & 0.0153 \\
\hline$t-5$ & -0.0004 & 0.2227 & 0.0051 & 0.0017 & 0.0126 \\
\hline$t-4$ & -0.0004 & 0.2223 & 0.0049 & 0.0017 & $0.0442 * * *$ \\
\hline$t-3$ & $0.0008 * * *$ & 0.2238 & 0.0209 & 0.0017 & $0.0277^{*}$ \\
\hline$t-2$ & 0.0004 & 0.2220 & -0.0026 & 0.0017 & $0.0255^{*}$ \\
\hline$t-1$ & -0.0000 & 0.2213 & -0.0031 & 0.0017 & $0.0575 * * *$ \\
\hline Announce & 0.0001 & 0.2234 & 0.0091 & 0.0019 & $0.2238 * * *$ \\
\hline$t+1$ & 0.0004 & 0.2262 & $0.0408 * * *$ & 0.0021 & $0.3074 * * *$ \\
\hline$t+2$ & 0.0003 & 0.2270 & $0.0409 * * *$ & 0.0019 & $0.2060 * * *$ \\
\hline$t+3$ & -0.0000 & 0.2240 & 0.0173 & 0.0018 & $01273 * * *$ \\
\hline$t+4$ & 0.0003 & 0.2227 & 0.0046 & 0.0017 & $0.1006^{* * *}$ \\
\hline$t+5$ & -0.0004 & 0.2231 & 0.0138 & 0.0017 & $0.0929 * * *$ \\
\hline$t+6$ & $-0.0004^{*}$ & 0.2214 & -0.0089 & 0.0017 & $0.0350 * *$ \\
\hline$t+7$ & -0.0002 & 0.2234 & 0.0077 & 0.0017 & $0.0289 * *$ \\
\hline$t+8$ & $-0.0005 * *$ & 0.2215 & -0.0134 & 0.0017 & $0.0243^{*}$ \\
\hline$t+9$ & $0.0004^{*}$ & 0.2228 & 0.0051 & 0.0016 & 0.0195 \\
\hline$t+10$ & -0.0002 & 0.2234 & 0.0172 & 0.0016 & 0.0110 \\
\hline
\end{tabular}

$* * *, * * * *$ Statistically significant at the $0.01,0.05$, or 0.10 levels 
Table 3

Event Study around Changes in Dividend Announcements

The table present results from a standard event study around dividend announcements. Panel A reports returns and short selling around dividend increases while panel B reports the event study results around dividend decreases. The short ratio (daily short volume divided by the daily trade volume) and the short turnover (daily short volume divided by the number of shares outstanding) are reported along with standardized measures of short selling. In order to standardize the short selling measures, we divide the difference between the short measure for stock $i$ on day $t$ and the average short measure for stock $i$ by the standard deviation of the short measure for stock $i$. The standardization procedure allows each stock to have a short measure on each day that is similarly distributed with a zero mean and a unit variance.

Results from $t$-tests are reported using asterisks. The $t$-test tests whether the standardized short measure is significantly different from zero.

\begin{tabular}{|c|c|c|c|c|c|}
\hline & $\begin{array}{c}\text { Market }-A d j . \\
\text { Returns }\end{array}$ & Short Ratio & $\begin{array}{l}\text { Standardized } \\
\text { Short Ratio }\end{array}$ & Short Turn & $\begin{array}{l}\text { Standardized } \\
\text { Short Turn }\end{array}$ \\
\hline$t-10$ & -0.0004 & 0.2183 & 0.0185 & 0.0014 & 0.0107 \\
\hline$t-9$ & -0.0005 & 0.2201 & 0.0410 & 0.0014 & 0.0441 \\
\hline$t-8$ & 0.0004 & 0.2151 & 0.0029 & 0.0014 & -0.0186 \\
\hline$t-7$ & 0.0003 & 0.2141 & 0.0001 & 0.0014 & 0.0049 \\
\hline$t-6$ & $0.0020 * * *$ & 0.2087 & -0.0438 & 0.0014 & -0.0341 \\
\hline$t-5$ & 0.0003 & 0.2113 & -0.0513 & 0.0014 & -0.0418 \\
\hline$t-4$ & -0.0008 & 0.2067 & $-0.0792 * *$ & 0.0014 & -0.0361 \\
\hline$t-3$ & $0.0011^{* *}$ & 0.2114 & -0.0154 & 0.0014 & -0.0017 \\
\hline$t-2$ & -0.0004 & 0.2104 & -0.0462 & 0.0014 & -0.0463 \\
\hline$t-1$ & 0.0004 & 0.2090 & -0.0479 & 0.0014 & -0.0087 \\
\hline Announce & $0.0014 * *$ & 0.2104 & -0.0473 & 0.0018 & $0.3241 * * *$ \\
\hline$t+1$ & $0.0014 * *$ & 0.2133 & -0.0017 & 0.0019 & $0.4240 * * *$ \\
\hline$t+2$ & 0.0000 & 0.2163 & 0.0277 & 0.0017 & $0.2293 * * *$ \\
\hline$t+3$ & 0.0002 & 0.2172 & 0.0269 & 0.0016 & $0.1663 * * *$ \\
\hline$t+4$ & 0.0001 & 0.2179 & 0.0344 & 0.0015 & $0.1495^{* * *}$ \\
\hline$t+5$ & $-0.0009 *$ & 0.2136 & 0.0038 & 0.0015 & $0.1062 * * *$ \\
\hline$t+6$ & 0.0003 & 0.2103 & -0.0105 & 0.0015 & $0.0743^{* *}$ \\
\hline$t+7$ & -0.0002 & 0.2118 & -0.0205 & 0.0014 & 0.0158 \\
\hline$t+8$ & $-0.0010^{*}$ & .0 .2130 & -0.0081 & 0.0015 & 0.0339 \\
\hline$t+9$ & $0.0014 * *$ & 0.2151 & 0.0139 & 0.0015 & $0.0741 *$ \\
\hline$t+10$ & 0.0005 & 0.2157 & 0.0152 & 0.0014 & -0.0002 \\
\hline
\end{tabular}

$* * *, * * * *$ Statistically significant at the $0.01,0.05$, or 0.10 levels 


\begin{tabular}{|c|c|c|c|c|c|}
\hline & $\begin{array}{c}\text { Market-Adj. } \\
\text { Returns }\end{array}$ & Short Ratio & $\begin{array}{c}\text { Standardized } \\
\text { Short Ratio }\end{array}$ & Short Turn & $\begin{array}{c}\text { Standardized } \\
\text { Short Turn }\end{array}$ \\
\hline$t-10$ & -0.0000 & 0.2339 & $0.1591 *$ & 0.0021 & $0.2189 *$ \\
\hline$t-9$ & $-0.0029 * *$ & 0.2157 & -0.0301 & 0.0020 & 0.0945 \\
\hline$t-8$ & -0.0017 & 0.2123 & -0.05039 & 0.0021 & 0.0800 \\
\hline$t-7$ & -0.0027 & 0.2104 & $-0.1093 *$ & 0.0019 & -0.0693 \\
\hline$t-6$ & 0.0026 & 0.2154 & -0.0663 & 0.0019 & 0.0399 \\
\hline$t-5$ & -0.0007 & 0.2234 & 0.0172 & 0.0019 & 0.0750 \\
\hline$t-4$ & 0.0013 & 0.2152 & -0.0461 & 0.0020 & 0.0754 \\
\hline$t-3$ & 0.0022 & 0.2227 & 0.0041 & 0.0021 & 0.1340 \\
\hline$t-2$ & 0.0018 & 0.2159 & -0.0477 & 0.0022 & 0.1328 \\
\hline$t-1$ & 0.0025 & 0.2204 & 0.0369 & 0.0022 & $0.1949 *$ \\
\hline Announce & $-0.0048 *$ & 0.2165 & -0.0087 & 0.0025 & $0.5986^{* * *}$ \\
\hline$t+1$ & $0.0066^{*}$ & 0.2246 & 0.0554 & 0.0034 & $0.8607 * * *$ \\
\hline$t+2$ & 0.0032 & 0.2236 & 0.0162 & 0.0033 & $0.5319 * * *$ \\
\hline$t+3$ & 0.0021 & 0.2174 & -0.0280 & 0.0027 & $0.3587 * * *$ \\
\hline$t+4$ & -0.0009 & 0.2191 & -0.0085 & 0.0024 & $0.2804 * *$ \\
\hline$t+5$ & 0.0001 & 0.2259 & 0.0682 & 0.0025 & $0.3187 * * *$ \\
\hline$t+6$ & 0.0011 & 0.2191 & -0.0064 & 0.0023 & $0.2265^{* *}$ \\
\hline$t+7$ & -0.0003 & 0.2219 & 0.0192 & 0.0022 & $0.1666^{*}$ \\
\hline$t+8$ & -0.0000 & 0.2160 & -0.0685 & 0.0023 & $0.1671 *$ \\
\hline$t+9$ & -0.0007 & 0.2233 & 0.0356 & 0.0021 & 0.1099 \\
\hline$t+10$ & -0.0004 & 0.2240 & 0.0375 & 0.0020 & 0.0849 \\
\hline
\end{tabular}

$* * *, * * *$ Statistically significant at the $0.01,0.05$, or 0.10 levels 
Table 4

Panel Regression Results

The table reports the results of estimating the following equation.

$$
S h \_ \text {sell }_{i, t-5, t-1}=\beta_{0}+\beta_{1} \text { turn }_{i, t-5, t-1}+\beta_{2} \text { pvolt }_{i,-5,-t-1}+\beta_{3} \text { size }_{i, t}+\beta_{4} \text { sh_rat }_{i, t-10, t-6}+\beta_{5} \text { ret }_{i, t-5, t-1}+\beta_{6} \text { ret }_{i, t-10, t-6}+\beta_{7} \text { ret }_{i, t, t+2}+\beta_{8} D I V \Delta^{j}{ }_{t}+
$$

$$
\beta_{9} \text { ret }_{i, t+2} \times D I V \Delta^{j}{ }_{t}+\varepsilon_{i, t-5, t-1}
$$

The dependent variables are the short ratio and short turnover measured from day $t-5$ to day $t-1$, where day $t$ is the current trading day. The independent variables include turnover (turn), price volatility ( $p v o l t)$, market capitalization in \$billion (size), cumulative returns (ret), and lagged short-selling activity. We also include a dummy variable, DIV $\Delta$, which represents dividend changes. INC is equal to one if day $t$ is an increased dividend announcement day while $D E C$ is equal to one if day $t$ is a decreased dividend announcement day. We interact future returns (ret $\left.t_{t, t+2}\right)$ and the dummy variables to test whether short sellers are better at predicting negative returns prior to a changes in dividend announcement than during non-event times. A Hausman tests rejects the presence of random effects. However, we find observed differences across stocks and days.

Therefore, we control for stock and day fixed effects. $P$-values are reported in parentheses. 


\begin{tabular}{|c|c|c|c|c|c|c|c|c|}
\hline & \multicolumn{4}{|c|}{$S h \_r a t_{t-5, t-1}$} & \multicolumn{4}{|c|}{ Sh_Turn ${ }_{t-5, t-1}$} \\
\hline & {$[1]$} & [2] & {$[3]$} & {$[4]$} & {$[5]$} & [6] & {$[7]$} & {$[8]$} \\
\hline \multirow[t]{2}{*}{ Intercept } & $0.0805 * * *$ & $0.0805 * * *$ & $0.0805 * * *$ & $0.0805 * * *$ & $-0.0008 * * *$ & $-0.0008 * * *$ & $-0.0008 * * *$ & $-0.0008 * * *$ \\
\hline & $(0.000)$ & $(0.000)$ & $(0.000)$ & $(0.000)$ & $(0.000)$ & $(0.000)$ & $(0.000)$ & $(0.000)$ \\
\hline \multirow{2}{*}{ Turn $_{t-5, t-1}$} & $-1.0596 * * *$ & $-1.0596 * * *$ & $-1.0595 * * *$ & $-1.0596 * * *$ & $0.1629 * * *$ & $0.1629 * * *$ & $0.1629 * * *$ & $0.1629 * * *$ \\
\hline & $(0.000)$ & $(0.000)$ & $(0.000)$ & $(0.000)$ & $(0.000)$ & $(0.000)$ & $(0.000)$ & $(0.000)$ \\
\hline \multirow[t]{2}{*}{ Pvolt $_{t-5, t-1}$} & $0.6905 * * *$ & $0.6906 * * *$ & $0.6905 * * *$ & $0.6906 * * *$ & $0.0148 * * *$ & $0.0148 * * *$ & $0.0148 * * *$ & $0.0148 * * *$ \\
\hline & $(0.000)$ & $(0.000)$ & $(0.000)$ & $(0.000)$ & $(0.000)$ & $(0.000)$ & $(0.000)$ & $(0.000)$ \\
\hline \multirow[t]{2}{*}{ Size $_{t}$} & $0.0558 *$ & $0.0559 *$ & $0.0559 *$ & $0.0559 *$ & $0.0009 * *$ & $0.0009 * *$ & $0.0009 * *$ & $0.0009 * *$ \\
\hline & $(0.076)$ & $(0.075)$ & $(0.075)$ & $(0.075)$ & $(0.040)$ & (0.039) & (0.039) & (0.039) \\
\hline \multirow[t]{2}{*}{$S h \_r a t_{t-10, t-6}$} & $0.4766 * * *$ & $0.4766 * * *$ & $0.4766 * * *$ & $0.4766 * * *$ & $0.2480 * * *$ & $0.2480 * * *$ & $0.2480 * * *$ & $0.2480 * * *$ \\
\hline & $(0.000)$ & $(0.000)$ & $(0.000)$ & $(0.000)$ & $(0.000)$ & $(0.000)$ & $(0.000)$ & $(0.000)$ \\
\hline \multirow{2}{*}{$\operatorname{Ret}_{t-5 . t-1}$} & $0.4107 * * *$ & $0.4107 * * *$ & $0.4107 * * *$ & $0.4107 * * *$ & $0.0041 * * *$ & $0.0041 * * *$ & $0.0041 * * *$ & $0.0041 * * *$ \\
\hline & $(0.000)$ & $(0.000)$ & $(0.000)$ & $(0.000)$ & $(0.000)$ & $(0.000)$ & $(0.000)$ & $(0.000)$ \\
\hline \multirow[t]{2}{*}{$\operatorname{Ret}_{t-10, t-6}$} & $0.0747 * * *$ & $0.0748 * * *$ & $0.0747 * * *$ & $0.0748 * * *$ & $0.0015 * * *$ & $0.0015 * * *$ & $0.0015 * * *$ & $0.0015 * * *$ \\
\hline & $(0.000)$ & $(0.000)$ & $(0.000)$ & (0.000) & $(0.000)$ & $(0.000)$ & $(0.000)$ & $(0.000)$ \\
\hline \multirow[t]{2}{*}{$\operatorname{Ret}_{t, t+2}$} & $-0.0203 * * *$ & $-0.0203 * * *$ & $-0.0203 * * *$ & $-0.0202 * * *$ & $-0.0001 *$ & $-0.0001 *$ & $-0.0001 *$ & $-0.0001 * *$ \\
\hline & $(0.000)$ & $(0.000)$ & $(0.000)$ & $(0.000)$ & $(0.070)$ & $(0.063)$ & $(0.069)$ & $(0.042)$ \\
\hline \multirow[t]{2}{*}{$I N C_{t}$} & $-0.0056 * * *$ & $-0.0058 * * *$ & & & -0.0001 & -0.0001 & & \\
\hline & $(0.003)$ & $(0.003)$ & & & $(0.257)$ & $(0.233)$ & & \\
\hline \multirow[t]{2}{*}{$\operatorname{Ret}_{t, t+2} \times I N C_{t}$} & & 0.0566 & & & & 0.0006 & & \\
\hline & & $(0.283)$ & & & & $(0.391)$ & & \\
\hline \multirow[t]{2}{*}{$D E C_{t}$} & & & -0.0035 & -0.0034 & & & -0.0001 & -0.0001 \\
\hline & & & $(0.456)$ & $(0.469)$ & & & (0.699) & (0.607) \\
\hline \multirow[t]{2}{*}{$\operatorname{Ret}_{t, t+2} \times D E C_{t}$} & & & & -0.0474 & & & & $0.0041 * * *$ \\
\hline & & & & $(0.444)$ & & & & $(0.000)$ \\
\hline $\operatorname{Adj} R^{2}$ & 0.6127 & 0.6127 & 0.6127 & 0.6127 & 0.8336 & 0.8336 & 0.8336 & 0.8336 \\
\hline Stock FE & Yes & Yes & Yes & Yes & Yes & Yes & Yes & Yes \\
\hline Day FE & Yes & Yes & Yes & Yes & Yes & Yes & Yes & Yes \\
\hline
\end{tabular}


Table 5

Event Study around Ex-Dividend Days

The table present results from a standard event study around ex-dividend days. Market-adjusted returns and the CRSP raw returns less the CRSP equally-weighted index. The short ratio (daily short volume divided by the daily trade volume) and the short turnover (daily short volume divided by the number of shares outstanding) are reported along with standardized measures of short selling. In order to standardize the short selling measures, we divide the difference between the short measure for stock $i$ on day $t$ and the average short measure for stock $i$ by the standard deviation of the short measure for stock $i$. The standardization procedure allows each stock to have a short measure on each day that is similarly distributed with a zero mean and a unit variance. Results from $t$-tests are reported using asterisks. The $t$ test tests whether the standardized short measure is significantly different from zero.

\begin{tabular}{|c|c|c|c|c|c|}
\hline & $\begin{array}{l}\text { Market-Adj. } \\
\text { Returns }\end{array}$ & Short Ratio & $\begin{array}{c}\text { Standardized } \\
\text { Short Ratio }\end{array}$ & Short Turn & $\begin{array}{l}\text { Standardized } \\
\text { Short Turn }\end{array}$ \\
\hline$t-10$ & 0.0003 & 0.2201 & -0.0154 & 0.0017 & $0.0272^{*}$ \\
\hline$t-9$ & 0.0000 & 0.2209 & -0.0115 & 0.0017 & $0.0461 * * *$ \\
\hline$t-8$ & 0.0003 & 0.2211 & -0.0046 & 0.0017 & $0.0588 * * *$ \\
\hline$t-7$ & -0.0001 & 0.2204 & $-0.0263^{*}$ & 0.0017 & 0.0238 \\
\hline$t-6$ & 0.0002 & 0.2227 & 0.0061 & 0.0017 & $0.0663 * * *$ \\
\hline$t-5$ & -0.0002 & 0.2208 & -0.0127 & 0.0017 & $0.0837 * * *$ \\
\hline$t-4$ & $-0.0004 *$ & 0.2201 & -0.0165 & 0.0017 & $0.0513 * * *$ \\
\hline$t-3$ & 0.0002 & 0.2193 & $-0.0281 * *$ & 0.0016 & 0.0140 \\
\hline$t-2$ & -0.0002 & 0.2176 & $-0.0499 * * *$ & 0.0016 & -0.0190 \\
\hline$t-1$ & 0.0002 & 0.2182 & $-0.0390 * * *$ & 0.0017 & $0.0581 * * *$ \\
\hline Ex-Day & $0.0007 * *$ & 0.2234 & $0.0154 *$ & 0.0016 & $0.0816 * * *$ \\
\hline$t+1$ & 0.0002 & 0.2250 & $0.0411 * * *$ & 0.0016 & $0.0214 * *$ \\
\hline$t+2$ & -0.0002 & 0.2240 & $0.0224^{*}$ & 0.0016 & $0.0191 *$ \\
\hline$t+3$ & 0.0003 & 0.2230 & 0.0152 & 0.0016 & 0.0168 \\
\hline$t+4$ & 0.0001 & 0.2220 & 0.0056 & 0.0017 & $0.0287 * *$ \\
\hline$t+5$ & $-0.0008 * * *$ & 0.2214 & 0.0037 & 0.0017 & $0.0218^{*}$ \\
\hline$t+6$ & $-0.0003 *$ & 0.2224 & 0.0102 & 0.0017 & 0.0083 \\
\hline$t+7$ & 0.0000 & 0.2219 & 0.0048 & 0.0016 & -0.0050 \\
\hline$t+8$ & 0.0001 & 0.2250 & $0.0343 * *$ & 0.0016 & -0.0200 \\
\hline$t+9$ & -0.0001 & 0.2208 & -0.0030 & 0.0016 & -0.0190 \\
\hline$t+10$ & 0.0002 & 0.2229 & 0.0194 & 0.0016 & -0.0120 \\
\hline
\end{tabular}

$* * *, * * * *$ Statistically significant at the $0.01,0.05$, or 0.10 levels 
Table 6

Event Study around Ex-Dividend Days

The table present results from a standard event study around ex-dividend days. Market-adjust returns, which are calculated by taking the difference between the CRSP raw return and the equally-weighted CRSP index return. Results from $t$-tests are reported using asterisks. The $t$-test tests whether the standardized short measure is significantly different from zero.

\begin{tabular}{lcccc}
\hline & $\begin{array}{c}\text { Dividend Yield } \\
\text { Quartile I }\end{array}$ & $\begin{array}{c}\text { Dividend Yield } \\
\text { Quartile II }\end{array}$ & $\begin{array}{c}\text { Dividend Yield } \\
\text { Quartile III }\end{array}$ & $\begin{array}{c}\text { Dividend Yield } \\
\text { Quartile IV }\end{array}$ \\
\hline ret $_{t-10, t-6}$ & & & & \\
ret $_{t-5, t-1}$ & 0.0009 & 0.0001 & 0.0010 & 0.0006 \\
ret $_{t, t+5}$ & $(0.455)$ & $(0.932)$ & $(0.325)$ & $(0.496)$ \\
& -0.0020 & -0.0009 & -0.0007 & $0.0017 * *$ \\
ret $_{t+6, t+10}$ & $(0.142)$ & $(0.411)$ & $(0.449)$ & $0.027)$ \\
& -0.0010 & -0.0004 & 0.0019 & $(0.749)$ \\
& $(0.196)$ & $(0.749)$ & $(0.143)$ & -0.0005 \\
& -0.0010 & -0.0002 & 0.0018 & $(0.210)$ \\
\hline
\end{tabular}

***,**,* Statistically significant at the $0.01,0.05$, or 0.10 levels 
Table 7

Event Study by Dividend Yield Quartiles

The table present results from a standard event study around ex-dividend days by dividend yield. The short ratio (Panel A) and the short turnover (Panel B) are reported along with standardized measures of short selling. In order to standardize the short selling measures, we divide the

difference between the short measure for stock $i$ on day $t$ and the average short measure for stock $i$ by the standard deviation of the short measure for stock $i$. The standardization procedure allows each stock to have a short measure on each day that is similarly distributed with a zero mean and a unit variance. Results from t-tests are reported using asterisks. The $t$-test tests whether the standardized short measure is significantly different from zero.

\begin{tabular}{|c|c|c|c|c|c|c|c|c|}
\hline & Yield & iartile I & Yield & artile II & Yield $Q$ & artile III & Yield $\mathrm{C}$ & artile IV \\
\hline & Short Ratio & $\begin{array}{c}\text { Standardized } \\
\text { Short Ratio }\end{array}$ & Short Ratio & $\begin{array}{c}\text { Standardized } \\
\text { Short Ratio }\end{array}$ & Short Ratio & $\begin{array}{c}\text { Standardized } \\
\text { Short Ratio }\end{array}$ & Short Ratio & $\begin{array}{l}\text { Standardized } \\
\text { Short Ratio }\end{array}$ \\
\hline$t-10$ & 0.2224 & -0.0090 & 0.2219 & -0.0311 & 0.2159 & -0.0302 & 0.2200 & 0.0088 \\
\hline$t-9$ & 0.2224 & -0.0144 & 0.2258 & -0.0085 & 0.2208 & 0.0133 & 0.2147 & -0.0374 \\
\hline$t-8$ & 0.2201 & -0.0280 & 0.2255 & 0.0020 & 0.2200 & 0.0068 & 0.2186 & 0.0013 \\
\hline$t-7$ & 0.2223 & -0.0240 & 0.2232 & -0.0309 & 0.2205 & -0.0115 & 0.2154 & -0.0388 \\
\hline$t-6$ & 0.2256 & 0.0226 & 0.2270 & 0.0096 & 0.2213 & 0.0151 & 0.2168 & -0.0227 \\
\hline$t-5$ & 0.2201 & -0.0430 & 0.2231 & -0.0432 & 0.2196 & 0.0071 & 0.2204 & 0.0280 \\
\hline$t-4$ & 0.2179 & $-0.0650 * *$ & 0.2249 & -0.0032 & 0.2182 & -0.0107 & 0.2196 & 0.0131 \\
\hline$t-3$ & 0.2198 & -0.0480 & 0.2226 & -0.0302 & 0.2165 & -0.0301 & 0.2183 & -0.0045 \\
\hline$t-2$ & 0.2195 & -0.0520 & 0.2213 & $-0.0543^{*}$ & 0.2135 & -0.0543 & 0.2159 & -0.0389 \\
\hline$t-1$ & 0.2188 & $-0.0600 * *$ & 0.2206 & $-0.0594 * *$ & 0.2159 & -0.0278 & 0.2175 & -0.0091 \\
\hline Ex-Day & 0.2208 & $-0.0460 *$ & 0.2258 & 0.0082 & 0.2272 & $0.0904 * * *$ & 0.2200 & 0.0055 \\
\hline$t+1$ & 0.2245 & 0.0029 & 0.2223 & -0.0176 & 0.2273 & $0.1056 * * *$ & 0.2258 & $0.0737 * * *$ \\
\hline$t+2$ & 0.2235 & -0.0140 & 0.2253 & -0.0051 & 0.2247 & $0.0679 * *$ & 0.2224 & $0.0408^{*}$ \\
\hline$t+3$ & 0.2217 & -0.0120 & 0.2269 & 0.0125 & 0.2242 & 0.0429 & 0.2192 & 0.0174 \\
\hline$t+4$ & 0.2209 & -0.0150 & 0.2248 & -0.0129 & 0.2223 & 0.0360 & 0.2198 & 0.0143 \\
\hline$t+5$ & 0.2200 & -0.0210 & 0.2213 & -0.0391 & 0.2229 & 0.0427 & 0.2212 & 0.0317 \\
\hline$t+6$ & 0.2204 & -0.0360 & 0.2233 & -0.0161 & 0.2236 & $0.0484 *$ & 0.2223 & $0.0448^{*}$ \\
\hline$t+7$ & 0.2252 & 0.0096 & 0.2246 & -0.0225 & 0.2200 & 0.0276 & 0.2178 & 0.0045 \\
\hline$t+8$ & 0.2215 & -0.0330 & 0.2300 & $0.0540 * *$ & 0.2210 & 0.0404 & 0.2271 & $0.0759 * *$ \\
\hline$t+9$ & 0.2171 & $-0.0740 * * *$ & 0.2244 & 0.0008 & 0.2198 & 0.0219 & 0.2217 & 0.0394 \\
\hline$t+10$ & 0.2207 & -0.0390 & 0.2261 & 0.0119 & 0.2228 & $0.0551 *$ & 0.2221 & $0.0496 *$ \\
\hline
\end{tabular}




\begin{tabular}{|c|c|c|c|c|c|c|c|c|}
\hline \multicolumn{9}{|c|}{ Panel B. Short Turnover by Dividend Yield } \\
\hline & \multicolumn{2}{|c|}{ Yield Quartile I } & \multicolumn{2}{|c|}{ Yield Quartile II } & \multicolumn{2}{|c|}{ Yield Quartile III } & \multicolumn{2}{|c|}{ Yield Quartile IV } \\
\hline & Short Turn & $\begin{array}{c}\text { Standardized } \\
\text { Short Turn }\end{array}$ & Short Turn & $\begin{array}{c}\text { Standardized } \\
\text { Short Turn }\end{array}$ & Short Turn & $\begin{array}{c}\text { Standardized } \\
\text { Short Turn }\end{array}$ & Short Turn & $\begin{array}{c}\text { Standardized } \\
\text { Short Turn }\end{array}$ \\
\hline$t-10$ & 0.0023 & 0.0447 & 0.0018 & $0.0551 *$ & 0.0015 & 0.0019 & 0.0011 & 0.0071 \\
\hline$t-9$ & 0.0023 & $0.0886 * * *$ & 0.0018 & $0.0738 * *$ & 0.0015 & 0.0325 & 0.0011 & -0.0105 \\
\hline$t-8$ & 0.0023 & $0.0599 * *$ & 0.0018 & $0.0891 * * *$ & 0.0015 & 0.0495 & 0.0011 & 0.0366 \\
\hline$t-7$ & 0.0023 & $0.0513 *$ & 0.0018 & $0.0634 * *$ & 0.0015 & -0.0119 & 0.0011 & -0.0076 \\
\hline$t-6$ & 0.0024 & $0.0870 * * *$ & 0.0018 & 0.0387 & 0.0015 & $0.0721 * *$ & 0.0012 & $0.0676 * *$ \\
\hline$t-5$ & 0.0023 & $0.0569 *$ & 0.0018 & $0.0489 *$ & 0.0015 & $0.0749 * *$ & 0.0013 & $0.1541 * * *$ \\
\hline$t-4$ & 0.0023 & $0.0561 * *$ & 0.0018 & 0.0355 & 0.0015 & 0.0143 & 0.0012 & $0.0994 * * *$ \\
\hline$t-3$ & 0.0022 & -0.0263 & 0.0017 & -0.0375 & 0.0014 & 0.0286 & 0.0012 & $0.0911 * * *$ \\
\hline$t-2$ & 0.0021 & -0.0329 & 0.0016 & $-0.0535 * *$ & 0.0014 & $-0.0533^{*}$ & 0.0011 & $0.0640 * *$ \\
\hline$t-1$ & 0.0022 & -0.0674 & 0.0018 & 0.0343 & 0.0015 & 0.0347 & 0.0012 & $0.1698 * * *$ \\
\hline$E x-D a y$ & 0.0022 & 0.0082 & 0.0018 & $0.0659 * *$ & 0.0017 & $0.0844 * * *$ & 0.0012 & $0.1677 * * *$ \\
\hline$t+1$ & 0.0022 & 0.0124 & 0.0017 & -0.0169 & 0.0015 & $0.0480 *$ & 0.0012 & $0.0420 * *$ \\
\hline$t+2$ & 0.0022 & 0.0275 & 0.0017 & -0.0144 & 0.0015 & 0.0279 & 0.0011 & 0.0355 \\
\hline$t+3$ & 0.0021 & -0.0035 & 0.0017 & 0.0170 & 0.0015 & 0.0480 & 0.0011 & 0.0055 \\
\hline$t+4$ & 0.0022 & 0.0043 & 0.0018 & $0.0649 * *$ & 0.0015 & 0.0382 & 0.0011 & 0.0073 \\
\hline$t+5$ & 0.0022 & 0.0174 & 0.0017 & 0.0276 & 0.0015 & 0.0275 & 0.0011 & 0.0146 \\
\hline$t+6$ & 0.0022 & 0.0050 & 0.0018 & 0.0172 & 0.0015 & 0.0032 & 0.0011 & 0.0076 \\
\hline$t+7$ & 0.0022 & 0.0202 & 0.0017 & 0.0176 & 0.0015 & -0.0357 & 0.0011 & -0.0216 \\
\hline$t+8$ & 0.0021 & -0.0250 & 0.0016 & $-0.0504 * *$ & 0.0015 & -0.0025 & 0.0011 & -0.0032 \\
\hline$t+9$ & 0.0021 & $-0.0543 * *$ & 0.0017 & -0.0133 & 0.0015 & -0.0153 & 0.0011 & 0.0072 \\
\hline$t+10$ & 0.0021 & -0.0046 & 0.0017 & -0.0122 & 0.0015 & -0.0218 & 0.0011 & -0.0089 \\
\hline
\end{tabular}


Table 8

Panel Regression Results

The table reports the results of estimating the following equation.

$$
\begin{aligned}
& S h \_s e l l_{i, t, t+4}=\beta_{0}+\beta_{1} t_{u r n} i_{i, t+t+4}+\beta_{2} \text { pvolt }_{i, t, t+4}+\beta_{3} \text { size }_{i, t}+\beta_{4} \text { sh_sell }_{i, t-5, t-1}+\beta_{5} \text { ret }_{i, t, t+4}+\beta_{6} \text { ret }_{i, t-5, t-7}+\beta_{7} \text { ret }_{i, t+5, t+1}+\beta_{8} E X_{t}+ \\
& \beta_{9} \text { ret }_{i, t+5, t+7} \times E X_{t}+\varepsilon_{i, t, t+4}
\end{aligned}
$$

The dependent variables are the short ratio and short turnover measured from day $t-5$ to day $t-1$, where day $t$ is the current trading day. The independent variables include turnover (turn), price volatility ( pvolt), market capitalization in \$billion (size), cumulative returns (ret), and lagged short-selling activity. We also include a dummy variable, $E X$, equal to one if day $t$ is an ex-dividend day. We also include a variable, $E X+$, which is equal to the dividend yield if day $t$ is an ex-dividend day; zero otherwise. We interact future returns $\left(\operatorname{ret}_{t+5, t+7)}\right)$ and the dummy variable $E X$, as well as the truncated variable $E X+$, to test whether short sellers are better at predicting negative returns on and after the ex-dividend day than during non-event times. A Hausman tests rejects the presence of random effects. However, we find observed differences across stocks and days. Therefore, we control for stock and day fixed effects. $P$-values are reported in parentheses. 


\begin{tabular}{|c|c|c|c|c|c|c|c|c|}
\hline & \multicolumn{4}{|c|}{$S h \_r a t_{t, t+4}$} & \multicolumn{4}{|c|}{$S h_{-}$Turn $_{t, t+4}$} \\
\hline & {$[1]$} & [2] & [3] & [4] & {$[5]$} & [6] & [7] & [8] \\
\hline Intercept & $\begin{array}{c}0.0716^{* * * *} \\
(0.000)\end{array}$ & $\begin{array}{c}0.0716 * * * \\
(0.000)\end{array}$ & $\begin{array}{c}0.0716 * * * \\
(0.000)\end{array}$ & $\begin{array}{c}0.0716 * * * \\
(0.000)\end{array}$ & $\begin{array}{c}-0.0006 * * * \\
(0.000)\end{array}$ & $\begin{array}{c}-0.0006 * * * \\
(0.000)\end{array}$ & $\begin{array}{c}-0.0006 * * * \\
(0.000)\end{array}$ & $\begin{array}{c}-0.0006 * * * \\
(0.000)\end{array}$ \\
\hline Turn $_{t, t+4}$ & $\begin{array}{c}-1.0371 * * * \\
(0.000)\end{array}$ & $\begin{array}{c}-1.0371 * * * \\
(0.000)\end{array}$ & $\begin{array}{c}-1.0367 * * * \\
(0.000)\end{array}$ & $\begin{array}{c}-1.0365 * * * \\
(0.000)\end{array}$ & $\begin{array}{c}0.1650 * * * \\
(0.000)\end{array}$ & $\begin{array}{c}0.1650 * * * \\
(0.000)\end{array}$ & $\begin{array}{c}0.1650 * * * \\
(0.000)\end{array}$ & $\begin{array}{c}0.1650 * * * \\
(0.000)\end{array}$ \\
\hline Pvolt $_{t, t+4}$ & $\begin{array}{c}0.6966 * * * \\
(0.000)\end{array}$ & $\begin{array}{c}0.6967 * * * \\
(0.000)\end{array}$ & $\begin{array}{c}0.6972 * * * \\
(0.000)\end{array}$ & $\begin{array}{c}0.6971 * * * \\
(0.000)\end{array}$ & $\begin{array}{c}0.0145 * * * \\
(0.000)\end{array}$ & $\begin{array}{c}0.0145 * * * \\
(0.000)\end{array}$ & $\begin{array}{c}0.0146 * * * \\
(0.000)\end{array}$ & $\begin{array}{c}0.0146 * * * \\
(0.000)\end{array}$ \\
\hline Size $_{t}$ & $\begin{array}{l}0.0187 \\
(0.275)\end{array}$ & $\begin{array}{l}0.0191 \\
(0.270)\end{array}$ & $\begin{array}{l}0.0188 \\
(0.270)\end{array}$ & $\begin{array}{l}0.0191 \\
(0.271)\end{array}$ & $\begin{array}{c}0.0014 * * * \\
(0.001)\end{array}$ & $\begin{array}{c}0.0014 * * * \\
(0.001)\end{array}$ & $\begin{array}{c}0.0014 * * * \\
(0.001)\end{array}$ & $\begin{array}{c}0.0014 * * * \\
(0.001)\end{array}$ \\
\hline$S h \_r a t_{t-5, t-1}$ & $\begin{array}{c}0.4726^{* * * *} \\
(0.000)\end{array}$ & $\begin{array}{c}0.4726^{* * * *} \\
(0.000)\end{array}$ & $\begin{array}{c}0.4726 * * * \\
(0.000)\end{array}$ & $\begin{array}{c}0.4726 * * * \\
(0.000)\end{array}$ & $\begin{array}{c}0.2330 * * * \\
(0.000)\end{array}$ & $\begin{array}{c}0.2330 * * * \\
(0.000)\end{array}$ & $\begin{array}{c}0.2330 * * * \\
(0.000)\end{array}$ & $\begin{array}{c}0.2330 * * * \\
(0.000)\end{array}$ \\
\hline $\operatorname{Ret}_{t, t+4}$ & $\begin{array}{c}0.4018 * * * \\
(0.000)\end{array}$ & $\begin{array}{c}0.4019 * * * \\
(0.000)\end{array}$ & $\begin{array}{c}0.4019 * * * \\
(0.000)\end{array}$ & $\begin{array}{c}0.4018 * * * \\
(0.000)\end{array}$ & $\begin{array}{c}0.0040 * * * \\
(0.000)\end{array}$ & $\begin{array}{c}0.0040 * * * \\
(0.000)\end{array}$ & $\begin{array}{c}0.0040 * * * \\
(0.000)\end{array}$ & $\begin{array}{c}0.0040 * * * \\
(0.000)\end{array}$ \\
\hline $\operatorname{Ret}_{t-5, t-1}$ & $\begin{array}{c}0.0721 * * * \\
(0.000)\end{array}$ & $\begin{array}{c}0.0723 * * * \\
(0.000)\end{array}$ & $\begin{array}{c}0.0721 * * * \\
(0.000)\end{array}$ & $\begin{array}{c}0.0723 * * * \\
(0.000)\end{array}$ & $\begin{array}{c}0.0015 * * * \\
(0.000)\end{array}$ & $\begin{array}{c}0.0015 * * * \\
(0.000)\end{array}$ & $\begin{array}{c}0.0015 * * * \\
(0.000)\end{array}$ & $\begin{array}{c}0.0015^{* * *} * \\
(0.000)\end{array}$ \\
\hline $\operatorname{Ret}_{t+5, t+7}$ & $\begin{array}{c}-0.0202 * * * \\
(0.000)\end{array}$ & $\begin{array}{c}-0.0191 * * * \\
(0.000)\end{array}$ & $\begin{array}{c}-0.0203 * * * \\
(0.000)\end{array}$ & $\begin{array}{c}-0.0196 * * * \\
(0.000)\end{array}$ & $\begin{array}{r}-0.0001 \\
(0.112)\end{array}$ & $\begin{array}{r}-0.0001 \\
(0.151)\end{array}$ & $\begin{array}{r}-0.0001 \\
(0.113)\end{array}$ & $\begin{array}{r}-0.0001 \\
(0.168)\end{array}$ \\
\hline$E X_{t}$ & $\begin{array}{c}0.0022 * * * \\
(0.003)\end{array}$ & $\begin{array}{c}0.0021 * * * \\
(0.007)\end{array}$ & & & $\begin{array}{c}0.0001 * * \\
(0.030)\end{array}$ & $\begin{array}{c}0.0001 * * \\
(0.033)\end{array}$ & & \\
\hline $\operatorname{Ret}_{t+5, t+7} \times E X_{t}$ & & $\begin{array}{c}-0.0837 * * * \\
(0.003)\end{array}$ & & & & $\begin{array}{c}-0.0007 * * \\
(0.049)\end{array}$ & & \\
\hline$E X+{ }_{t}$ & & & $\begin{array}{c}0.0020 * \\
(0.056)\end{array}$ & $\begin{array}{c}0.0020 * \\
(0.054)\end{array}$ & & & $\begin{array}{l}0.0000 \\
(0.350)\end{array}$ & $\begin{array}{l}0.0000 \\
(0.334)\end{array}$ \\
\hline $\operatorname{Ret}_{t+5, t+7} \times E X+_{t}$ & & & & $\begin{array}{c}-0.1155^{* *} \\
(0.019)\end{array}$ & & & & $\begin{array}{c}-0.0019 * * * \\
(0.002)\end{array}$ \\
\hline $\operatorname{Adj} R^{2}$ & 0.6116 & 0.6116 & 0.6115 & 0.6116 & 0.8317 & 0.8317 & 0.8317 & 0.8317 \\
\hline Stock FE & Yes & Yes & Yes & Yes & Yes & Yes & Yes & Yes \\
\hline Day FE & Yes & Yes & Yes & Yes & Yes & Yes & Yes & Yes \\
\hline
\end{tabular}




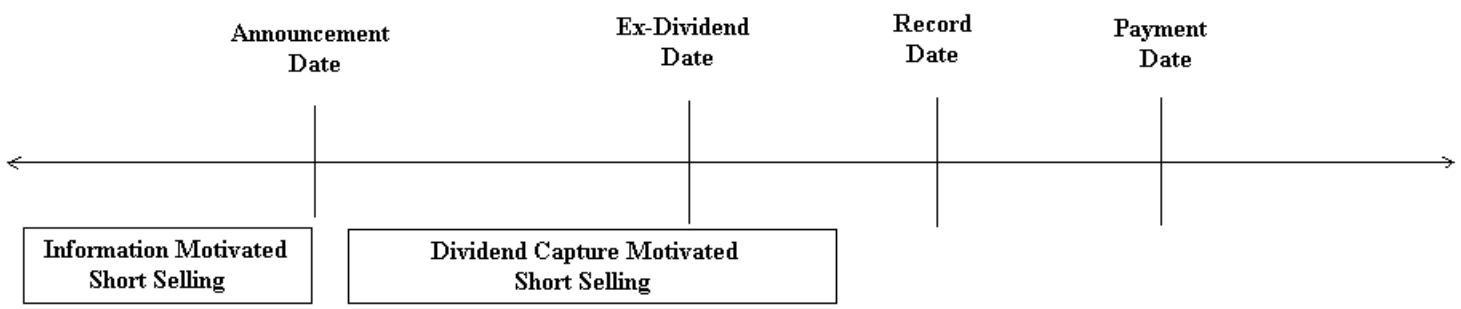

Figure 1. The figure shows the motivation for short selling around dividends. Short sellers around the announcement date are likely informed about the announcement, while short sellers around the ex-dividend date are likely motivated by dividend capturers. 